Indré Žvaigždinienè

Katedra Prawa Publicznego

Uniwersytet Wileński

\title{
Ingrida Danéliené
}

Katedra Prawa Publicznego

Uniwersytet Wileński

\section{ASPEKTY KONSTYTUCYJNE STATUSU SĄDÓW ADMINISTRACYJNYCH LITWY ORAZ ICH SĘDZIÓW}

Konstytucja określa status systemu sądownictwa jako jednej z trzech władz w państwie na równi z władzą ustawodawczą i wykonawczą, w celu zapewnienia jej samodzielności, nadania sądom kompetencji zgodnej z ich przeznaczeniem, a jednocześnie w celu określenia ich stosunku do innych instytucji władzy państwowej. Bezpośrednie określenie zakresu kompetencji w Konstytucji oznacza, że jedna instytucja władzy państwowej nie może przejąć, przekazać uprawnień innej instytucji lub z nich zrezygnować. Takie uprawnienia nie mogą być zastąpione lub ograniczone przez określenie w przepisach prawa dodatkowych warunków ich realizacji ${ }^{1}$.

Część 1 artykułu 111 określa system sądownictwa powszechnego i wskazuje, że składa się on z Sądu Naczelnego Republiki Litewskiej, Sądu Apelacyjnego Republiki Litewskiej, sądów okręgowych i rejonowych. Część 2 artykułu 111 Konstytucji określa, że w celu rozpatrywania spraw z zakresu prawa administracyjnego, prawa pracy, prawa rodzinnego i innych zgodnie z przepisami prawa mogą być założone inne sądy specjalistyczne. Warto zaznaczyć, że ustawodawca w regulowaniu stosunków dotyczących zakładania sądów specjalistycznych oraz ich działalności - chociaż posiada szeroki zakres swobody regulacyjnej (kierując się zasadą inter alia) w decydowaniu o tym, do rozstrzygania jakich kategorii spraw powinny być za-

\footnotetext{
${ }^{1}$ Postanowienie Sądu Konstytucyjnego Republiki Litewskiej z dnia 21 kwietnia 1998 r.
} 
łożone sądy specjalistyczne, w ustalaniu systemu sądów specjalistycznych przeznaczonych do rozstrzygania każdej kategorii spraw, składu liczebnościowego i stosunków z sądami powszechnymi oraz zakładania sądów specjalistycznych do rozstrzygania spraw innych kategorii - powinien uwzględniać założenia Konstytucji o podstawach instancyjnego systemu sądownictwa ${ }^{2}$. W tym kontekście należy podkreślić iż, jak stwierdza Sąd Konstytucyjny w swoim orzeczeniu z dnia 16 stycznia 2006 r., instancyjny system sądownictwa jest zatwierdzony inter alia w cz. 1 i 2 artykułu 111 Konstytucji (aczkolwiek nie tylko w przepisach Konstytucji). Konstytucja, o ile jej założenia są wyjaśniane systematycznie, zakłada, że instancyjny system sądownictwa jest ustalony nie tylko dla sądów powszechnych, lecz zgodnie z cz. 2 artykułu 111 Konstytucji - dla założonych sądów specjalistycznych. Należy zaznaczyć, że w oparciu o cz. 2 artykułu 111 Konstytucji, instancyjny system sądów specjalistycznych w porównaniu z instancyjnym systemem sądów powszechnych może posiadać pewne osobliwości. Aczkolwiek w oparciu o Konstytucję ustawodawca zgodnie z cz. 2 artykułu 111 Konstytucji nie może utworzyć takiego systemu (lub systemów) sądów specjalistycznych (jeśli jest więcej niż jedna kategoria spraw, w celu rozstrzygnięcia których są tworzone osobne sądy specjalistyczne), który (które) zasadniczo zmieniłby (zmieniłyby) system sądów powszechnych imperatywnie określony w Konstytucji i przejąłby (przejęłyby) większość funkcji systemu sądów powszechnych ${ }^{3}$. Należy zaznaczyć, że ustawodawca tworząc sądy specjalistyczne powinien także określić tryb konkurencji w sądownictwie między sądami specjalistycznymi a sądami powszechnymi oraz (jeśli jest więcej niż jedna kategoria spraw, do rozstrzygnięcia których są tworzone osobne sądy specjalistyczne) między sądami specjalistycznymi przeznaczonymi do rozstrzygnięcia jednej kategorii spraw a sądami specjalistycznymi przeznaczonymi do rozstrzygania spraw innej kategorii.

Obecnie na Litwie wybrano następujący model - sądy administracyjne niezależne od sądów powszechnych są jedynymi sądami specjalistycznymi na Litwie. Sądy administracyjne w Republice Litewskiej zostały założone po uchwaleniu w 1999 roku Ustawy Republiki Litewskiej o założeniu sądów administracyjnych. Kształtowanie się systemu sądownictwa administracyjnego ostatecznie zostało zakończone po uchwaleniu Ustawy o wprowadzeniu zmian i uzupełnień do art. 2, 3, 4, 5, 6 Ustawy Republiki Litewskiej o założeniu sądów administracyjnych, która weszła w życie w dn. (nenurodyta diena?) stycznia 2001 r. Ustawa ta określiła strukturę sądownictwa składającą się z Wileńskiego Okręgowego Sądu Administracyjnego, Kowieńskie-

\footnotetext{
${ }^{2}$ Postanowienie Sądu Konstytucyjnego Republiki Litewskiej z dnia 28 marca 2006 r.

${ }^{3}$ Tamże.
} 
go Okręgowego Sądu Administracyjnego, Kłajpedzkiego Okręgowego Sądu Administracyjnego, Poniewieskiego Okręgowego Sądu Administracyjnego, Szawelskiego Okręgowego Sądu Administracyjnego oraz Naczelnego Sądu Administracyjnego Republiki Litewskiej. Dwupionowy system sądownictwa administracyjnego działający na Litwie nie jest wyjątkowy. Wręcz przeciwnie, można rzec, że jest on zgodny z modelem instytucjonalnym prawa administracyjnego uznanym w Europie, działającym np. w Republice Finlandii, Rzeczypospolitej Polskiej, Wielkim Księstwie Luksemburga, Republice Czeskiej, Republice Austrii oraz w innych państwach Unii Europejskiej. Czyli uchwalenie wspomnianych aktów prawa można uważać za końcowy etap tworzenia demokratycznego systemu sądownictwa na Litwie. Po uchwaleniu tych ustaw wypełniono istotną lukę w systemie sądownictwa, ponieważ dotychczas na Litwie nie istniały specjalistyczne sądy administracyjne i pod tym względem Litwa pozostawała w tyle do innych demokratycznych państw Europy. Zdarzały się przypadki, gdy ze względu na osobliwości sporów administracyjnych oraz brak regulacji prawnych, część z nich w ogóle nie była rozpatrywana ${ }^{5}$.

Na mocy nowo uchwalonych ustaw do kompetencji założonych sądów administracyjnych przeszły skargi (wnioski) dotyczące wydanych przez podmioty administracji publicznej oraz wewnętrznej aktów administracyjnych lub czynności, ewentualnie braku czynności (tzn. niewykonania obowiązków) ${ }^{6}$. Dzisiaj sądy administracyjne rozpatrują wnioski dotyczące zgodności z prawem wydanych aktów i czynności podmiotów państwowych i podmiotów samorządowej administracji publicznej oraz dotyczące odmowy wykonania czynności wchodzących w zakres kompetencji tych instytucji lub zwlekania z wykonaniem takich czynności; pokrycia szkód powstałych na skutek działań podmiotów administracji publicznej niezgodnych z pra-

${ }^{4}$ Europejski portal e-Sprawiedliwość. System sądownictwa w Królestwie Belgii, https://e-justice.europa.eu/content_judicial_systems_in_member_states-16-be-lt.do?member=1/ [dostęp13.11.2014].

${ }^{5}$ Między innym jeszcze w art. 68 Konstytucji Republiki Litewskiej uchwalonej w $1922 \mathrm{r}$. zostało zatwierdzone założenie (które zostało wykreślone z Konstytucji Litwy z 1928 r. oraz z Konstytucji Litwy z 1938 r.) określające, że „O zgodności z prawem dekretów wydanych przez administrację decyduje sąd”. Zdaniem profesora Michała Römera - wybitnego prawnika konstytucjonalisty z okresu międzywojennego - to założenie nie zostało wdrożone w życie. W latach 1918-1940 sądy administracyjne na Litwie nie zostały założone. Zdaniem M. Römera, pozostałe sądy funkcjonujące na Litwie działały zgodnie z prawem i odmawiały rozstrzygania wniosków dotyczących zgodności z prawem aktów administracyjnych, ponieważ żaden z aktualnych wówczas aktów prawnych nie przydzielał spraw o podobnym charakterze do kompetencji żadnego z sądów (uwaga autora), M. Römeris, Administracinio teismo įstatymo projektas [Projekt Ustawy o Sądzie Administracyjnym], „Židinys” 1940, nr 1-6, s. 562.

${ }^{6}$ Art. 1 Ustawy Republiki Litewskiej o założeniu sądów administracyjnych [lit.: Lietuvos Respublikos administraciniu teismu įsteigimo įstatymas]. 
wem; zapłacenia, zwrotu lub odzyskania podatków, innych obowiązujących opłat, ceł, stosowania sankcji finansowych, jak również spory podatkowe; naruszenia przepisów prawa wyborczego oraz Ustawy o Referendum i in. Zgodnie z przepisami prawa, kompetencji sądów administracyjnych mogą podlegać inne sprawy, aczkolwiek sądy administracyjne nie rozstrzygają spraw podlegających kompetencjom Sądu Konstytucyjnego oraz sądów powszechnych. Kompetencjom sądów administracyjnych nie podlega rozstrzyganie spraw dotyczących działalności Prezydenta Republiki, Sejmu, posłów na Sejm, Premiera (Przewodniczącego Rady Ministrów), Rządu (jako organu kolegialnego), Sądu Konstytucyjnego, działalności sędziów Sądu Naczelnego Litwy oraz Sądu Apelacyjnego Litwy, sędziów innych sądów oraz czynności procesowych prokuratorów, funkcjonariuszy prowadzących postępowanie przedsądowe oraz komorników dotyczących sprawowania wymiaru sprawiedliwości lub postępowania w sprawie, a także realizacji decyzji (zaleceń) Rzecznika Praw Obywatelskich. W zasadzie sądom administracyjnym zleca się ocenę zgodności z prawem postanowień (czynności lub braku czynności) organów władzy wykonawczej. Ta funkcja jest niezwykle ważna, ponieważ kwestia zgodności aktów administracyjnych z prawem jest jedną z najbardziej istotnych części składowych doktryny demokratycznego państwa prawnego, ponieważ bez sądów administracyjnych (oraz bez Sądu Konstytucyjnego) niemożliwe jest zapewnienie należytej realizacji funkcji państwowych, dążenie do realizacji oczekiwań społeczeństwa w zakresie demokracji, sprawiedliwości i praworządności ${ }^{7}$. Podsumowując, można stwierdzić, że po założeniu sądów administracyjnych na Litwie nie tylko zakończono kształtowanie systemu sądownictwa na Litwie, lecz znacznie wzmocniono gwarancje ochrony praw i wolności człowieka w sądownictwie: sądy administracyjne, rozstrzygając spory między państwem a osobą prywatną, dokonując oceny zgodności z prawem normatywnych aktów administracji, które zostały uchwalone przez centralne podmioty administracji państwowej (centralne organy administracji państwowej), rozstrzygają kwestie legalności, pomagają zapewnić realizację założenia konstytucyjnego, że instytucje władzy służą ludziom.

Sąd Konstytucyjny Republiki Litewskiej w swojej doktrynie twierdzi, że obecnie zgodnie z Konstytucją i obowiązującymi przepisami prawa występują trzy samodzielne systemy sądownictwa: 1) Sąd Konstytucyjny zajmuje się konstytu cyjnym nadzorem sądowym; 2) wymienione w części 1 artykułu 111 Konstytucji: Litewski Sąd Naczelny, Litewski Sąd Apelacyjny, sądy okręgowe i rejonowe stanowią system sądowy ogólnej kompetencji; 3) na podsta-

${ }^{7}$ J. Žilys, Administraciniu teisés aktu teisètumo problema prof. Mykolo Romerio mokslo darbuose, „Jurisprudencija” 2005, vol. 64 (56), s. 19. 
wie zaleceń części 2 artykułu 111 Konstytucji został założony i działa jeden z systemów sądownictwa specjalistycznego - właśnie administracyjny, na który składają się Naczelny Sąd Administracyjny Litwy oraz okręgowe sądy administracyjne ${ }^{8}$. Chociaż te systemy sądowe są powiązane ze sobą, to każdy ma swoje przeznaczenie, tylko własne funkcje i nie ma między nimi stosunku podporządkowania. Jak wskazuje praktyka (można wyciągnąć pewne wnioski uogólniające, mając na uwadze to, że sądy administracyjne na Litwie działają już od ponad dziesięciu lat), taki model organizacji władzy sądowniczej funkcjonuje należycie. Skuteczność systemu sądownictwa administracyjnego na Litwie została potwierdzona na poziomie międzynarodowym. Europejski Trybunał Praw Człowieka ocenił sądy administracyjne Republiki Litewskiej jako należyty i skuteczny instrument ochrony praw człowieka, posiadający kompetencje do rozstrzygania sporów jednostki z państwem (zob. Orzeczenie ETPC z dnia 16 grudnia 2003 r. o dopuszczalności w sprawie Jankauskas przeciwko Litwie). Instytucje unijne stawiają model działający na Litwie za wzór dla innych państw zakładających sądy administracyjne (np. od 1 marca 2007 r. w Bułgarii funkcjonuje system sądownictwa administracyjnego identyczny jak ten funkcjonujący na Litwie). Praktyka sądów litewskich (w tym administracyjnych) w stosowaniu europejskich standardów w zakresie praw człowieka została pozytywnie oceniona w postanowieniach sądów międzynarodowych ${ }^{9}$. Można z tego wnioskować, że decyzja o tworzeniu specjalistycznych sądów administracyjnych była słuszna.

Dzisiaj powinniśmy zadać inne pytanie dotyczące statusu sądów administracyjnych. Należy zwrócić uwagę na to, że chociaż wymienione powyżej trzy systemy są równie ważne i posiadają równie ważne znaczenie dla zapewnienia funkcjonowania państwa prawa, to tylko pierwsze dwa są określone expressis verbis w Konstytucji. Kompetencje sądów administracyjnych, ich system instancyjny, podział sędziów i gwarancje określają przepisy prawa. Można dyskutować, czy ten poziom regulacji prawnej jest wystarczający? Czy poziom konstytucyjny nie byłby bardziej odpowiedni w celu zapewnienia niezawisłości sądów administracyjnych?

W tym kontekście należy przypomnieć, że, jak już podkreślił Sąd Konstytucyjny, stabilność Konstytucji jest taką jej cechą, która wraz z innymi inter alia, a przede wszystkim ze szczególną mocą prawną Konstytucji, konstytucyjne regulacje prawne oddziela od regulacji prawnych aktu prawnego

${ }^{8}$ Postanowienia Sądu Konstytucyjnego Republiki Litewskiej inter alia z dn. 13 grudnia 2004 r., 16 stycznia 2006 r., 28 marca 2006 r., 9 maja 2006 r., 6 czerwca 2006 r., 27 listopada 2006 r., 22 października 2007 r., 13 maja 2010 r.

${ }^{9}$ Na przykład zob. Orzeczenie ETPC z dn. 15 października 2013 r. w sprawie R. Savickas $i$ inni przeciwko Litwie, http://hudoc.echr.coe.int/sites/eng/pages/search.aspx\#\{„appno":[„66365/09”]\}/ [dostęp 13.11.2014]. 
niższego rzędu (ordynaryjnego). Z drugiej zaś strony, stabilność Konstytucji nie zaprzecza możliwości wprowadzenia do niej poprawek, gdy jest to konieczne z przyczyn obiektywnych (Orzeczenie Sądu Konstytucyjnego z dn. 14 marca 2006 r.). Należy jednak uwzględnić to, że wprowadzenie poprawek do Konstytucji nie może doprowadzić do powstania sprzeczności założeń Konstytucji wobec siebie oraz sprzeczności wzajemnej zatwierdzonych w niej wartości. Poprawka do Konstytucji nie może stworzyć takiej nowej konstytucyjnej regulacji prawnej, że jedna zasada Konstytucji zaprzeczałaby innej lub ją negowała i nie można by było interpretować tych zasad jako zgodnych ze sobą. Z Konstytucji wynika imperatyw, że poprawki do Konstytucji nie mogą naruszać zasad Konstytucji oraz harmonii wartości w niej utrwalonych ${ }^{10}$.

Dlatego w celu dokonania oceny potrzeb i możliwości określenia bezpośrednio w Konstytucji systemu sądownictwa administracyjnego, poszczególnych aspektów statusu sędziów tych sądów, należy uwzględnić:

- Czy taka regulacja prawna nie będzie sprzeczna z obowiązującą regulacją konstytucyjną, czy nie zostaną naruszone normy i zasady konstytucyjne oraz stabilność Konstytucji;

- Czy takie poprawki do Konstytucji wynikają z obiektywnej konieczności prawnej?

\section{Zgodność systemu sądownictwa administracyjnego z imperatywami konstytucyjnymi}

Gdy w Konstytucji nie został explicite utrwalony system sądownictwa administracyjnego, zgodnie z częścią 2 artykułu 111 działalność założonych sądów specjalistycznych składających się z Naczelnego Sądu Administracyjnego Litwy i okręgowych sądów administracyjnych oraz imperatywy regulacji prawnej tej działalności (w dużym stopniu stosowane wobec sądów powszechnych, jak i mutatis mutandi oraz sądów administracyjnych) są zatwierdzone w oficjalnych założeniach konstytucyjnych ${ }^{11}$. Oceniając odpowiednio z tego punktu widzenia zasadność dwupionowego instancyjnego systemu sądownictwa administracyjnego, można stwierdzić, że jest on w pełni zgodny z wymogami wynikającymi z Konstytucji. Powyższy wniosek

${ }^{10}$ Orzeczenie Sądu Konstytucyjnego Republiki Litewskiej z dn. 24 stycznia 2014 r.

${ }^{11}$ Orzeczenia Sądu Konstytucyjnego Republiki Litewskiej inter alia z dn. 13 grudnia 2004 r., 16 stycznia 2006 r., 28 marca 2006 r., 9 maja 2006 r., 6 czerwca 2006 r., 27 listopada 2006 r., 22 października 2007 r., 13 maja 2010 r. 
opiera się na tym, że obowiązujące przepisy prawne regulujące działalność sądów administracyjnych, a także oficjalna doktryna sądów administracyjnych (opierająca się na imperatywach zatwierdzonych w oficjalnej doktrynie Sądu Konstytucyjnego) zapewniają:

- po pierwsze, możliwość w określonym trybie zaskarżenia aktu końcowego wydanego przez sąd administracyjny przynajmniej przed jednym z sądów wyższej instancji, tj. obecna struktura instytucyjna sądownictwa administracyjnego zapewnia możliwość zaskarżenia przed sądem apelacyjnym każdego końcowego orzeczenia procesowego wydanego przez sąd pierwszej instancji; zgodnie z Ustawą Republiki Litewskiej o Wymiarze Sprawiedliwości w Postępowaniu Administracyjnym (dalej: UWSPA), Naczelny Sąd Administracyjny Litwy jest instancją apelacyjną w przypadku spraw, które zostały rozpatrzone przez sądy administracyjne jako sądy pierwszej instancji (art. 20, cz. 1, p. 1);

- po drugie, przesłanki prawne do kształtowania jednolitej praktyki sądowej powinny być w sposób wyraźny i racjonalny argumentowane, tj. powinna je cechować: przewidywalność decyzji sądowych w celu zapewnienia ciągłości jurysprudencji, obciążenie sądów (inter alia najwyższej instancji) istniejącymi przypadkami precedensowymi, korygowanie praktyki sądowej i tworzenie nowych precedensów sądowych tylko wówczas, gdy jest to nieuniknione, obiektywnie niezbędne. Stosując zasady UWSPA w podsumowaniu praktyki Naczelnego Sądu Administracyjnego Litwy, precedensy sądów administracyjnych są wymieniane jako jedno ze źródeł prawa administracyjnego procesowego - auctoritate rationis, zaś odwoływanie się do precedensów sądowych jest uznawane za warunek stosowania jednorodnej (konsekwentnej, niesprzecznej) praktyki sądowej, wraz ze stosowaniem zasady sprawiedliwości utrwalonej w Konstytucji ${ }^{12}$. W oparciu o oficjalną doktrynę konstytucyjną ${ }^{13}$ Naczelny Sąd Administracyjny wielokrotnie podkreślał, że precedensy nie mogą być ignorowane bez uzasadnienia. W decyzjach procesowych LNSA zaznaczano, że „wagę precedensu mają tylko takie poprzednie decyzje sądowe, które były wydane w analogicznych sprawach, tj. takie, których okoliczności faktyczne są identyczne lub bardzo podobne do okoliczności faktycznych sprawy, dla której był stworzony precedens i w których należy stosować te same przepisy prawa, jak i w sprawie, dla której został stworzony precedens" ${ }^{\prime 14}$. Przez to podkreśla się, że praktyka sądowa nie jest statyczna i może być zmieniana lub rozwijana przez sądy (tj. mogą być two-

${ }^{12}$ Administracinė jurisprudencija. Lietuvos vyriausiojo administracinio teismo biuletenis, 2012, Nr 23, s. 554.

${ }^{13}$ Orzeczenie Sądu Konstytucyjnego Republiki Litewskiej z dn. 24 października 2007 r.

${ }^{14}$ Tamże; Postanowienie Naczelnego Sądu Administracyjnego Republiki Litewskiej z dn. 18 listopada 2011 r. w sprawie administracyjnej $\mathrm{Nr} \mathrm{A}^{143}-2619 / 2011$. 
rzone nowe precedensy, poprawiające poprzednią praktykę sądową), gdy stanowi to nieuniknioną koniecznośćc ${ }^{15}$;

- po trzecie, wdrożenie imperatywu, że zgodnie z zasadami prawa zadaniem sądu każdej instancji jest wykonywanie tych funkcji, które są przydzielone sądowi danej instancji i nieprzekraczanie zakresu swojej jurysdykcji, nieprzekraczanie innych uprawnień. W oparciu o cz. 1 art. 142 UWSPA na podstawie nieważności decyzji są uznawane takie przypadki, gdy sprawa została rozpatrzona przed sądem, skład którego nie był zgodny z prawem lub naruszone zostały zasady dotyczące przeznaczenia funkcyjnego lub wyjątkowego podziału terytorialnego lub przepisy dotyczące jurysdykcji kategorii spraw dla sądu powszechnego lub sądu administracyjnego (zob. także art. 14-17, 4 UWSPA);

- po czwarte, niepodporządkowanie się organizacyjne i inne sądu niższej instancji jakiemukolwiek sądowi wyższej instancji, samodzielność procesową, niezależność w formowaniu praktyki sądowej, gdy sądy samodzielnie rozpatrują sprawy. Zgodnie z zasadą niezawisłości sędziowskiej żaden sędzia sądu administracyjnego nie powinien tłumaczyć się z powodu rozpatrywanych lub rozpatrzonych przez niego spraw, zaś podjęte przez niego decyzje procesowe można przeanalizować tylko zgodnie z przepisami prawa i w oparciu o ustawy (Cz. 4 art. 3.; art. 19; art. 21; cz. 1 art. 23 Ustawy o Sądzie), poza tym, podczas składania odwołań apelacyjnych, osobnych zażaleń, wniosków o wznowienie procesu sądowego (art. 37; art. 71; art. 127, art. 153-154 UWSPA). Przepisy prawa nie zezwalają na jakąkolwiek inną formę kontroli decyzji procesowych sądu, ponieważ byłaby ona sprzeczna z zasadą niezawisłości sądów (sędziowską).

Poza tym warto zaznaczyć, że zgodnie z obowiązującymi przepisami prawa (zob. art. 25-31 UWSPA), spory podlegające kompetencji sądu administracyjnego, zanim trafią do sądu administracyjnego, często (obowiązkowo lub fakultatywnie) w pierwszej kolejności są rozpatrywane w trybie przedsądowym, tj. indywidualne akty administracyjne uchwalone przez podmiot administracji publicznej lub czynności (brak czynności) mogą być, a w poszczególnych przypadkach powinny być poprzednio rozpatrywane przez instytucję rozstrzygającą spory w trybie pozasądowym. Odpowiednio - przez okręgowy sąd administracyjny, tj. w instytucji sądowej pierwszej instancji rozpatrującej spory dotyczące prawa administrowania publicznego, spór administracyjny jest często rozstrzygany po raz drugi lub trzeci - przedtem wspomniany powyżej spór często bywał rozstrzygany przez komisję ds. rozstrzygania sporów administracyjnych (ogólną lub specjalną) lub przez pod-

${ }^{15}$ Orzeczenie Sądu Konstytucyjnego Republiki Litewskiej z dnia 28 marca 2006 r.; Postanowienie Naczelnego Sądu Administracyjnego Republiki Litewskiej z dn. 18 listopada 2011 r. w sprawie administracyjnej $\mathrm{Nr} \mathrm{A}^{143}$-2619/2011. 
miot wyższej administracji publicznej. Warto również zaznaczyć, że zgodnie z przepisami prawa Unii Europejskiej poszczególne instytucje rozstrzygające spory w trybie przedsądowym są uznawane za instytucje sądowe, tj. wówczas, gdy spełniają one wymogi specjalne zatwierdzone w przepisach prawa UE, takie jak np. niezawisłość, ciągłość działalności i inne. Na mocy decyzji Trybunału Sprawiedliwości Unii Europejskiej (TSUE) z dn. 21 października 2010 r. w sprawie Nr C-385/09 Nidera Handescompagnie BV v. Państwowa Inspekcja Podatkowa przy Ministerstwie Finansów Republiki Litewskiej za taką instytucję uznano Komisję ds. Sporów Podatkowych przy Rządzie Republiki Litewskiej rozpatrującą spory podatkowe w trybie przedsądowym. Europejski Trybunał Praw Człowieka w orzeczeniu z 18 stycznia $2011 \mathrm{r}$. w sprawie Rikoma Ltd przeciwko Litwie, opierając się na cz. 1 art. 6 europejskiej Konwencji o ochronie praw człowieka i podstawowych wolności, jakby uzupełniając i w ten sposób potwierdzając przedstawioną przez TSUE interpretację przepisów prawa unijnego, wywnioskował, że tryb rozpatrywania sporów podatkowych na Litwie stanowi system „trzech instancji”.

Nieprzypadkowo wobec kandydatów na stanowisko sędziego do okręgowego sądu administracyjnego - pierwszej instancji prawnej, rozpatrującego sprawy administracyjne, są stawiane o wiele wyższe wymogi niż wobec kandydatów na sędziów do sądów rejonowych - rozpatrujących sprawy o kompetencji ogólnej, rozpatrujących w dużej mierze sprawy naruszenia przepisów prawa cywilnego, karnego, administracyjnego i są one zgodne z wymogami stawianymi wobec kandydatów na sędziów do sądów rejonowych, czyli sądów drugiego pionu, należących do sądów powszechnych.

W związku z powyższym należy stwierdzić, że obowiązujący obecnie na Litwie dwupionowy system sądów administracyjnych jest systemem optymalnym do realizowania celów określonych w prawie administracyjnym, zapewniającym skuteczne i szybkie rozpatrywanie spraw administracyjnych oraz całkowicie spełniającym wymogi Konstytucji.

\section{Status prawny (konstytucyjny) sędziów sądów administracyjnych}

Status prawny sędziego sądu stanowi jedną z gwarancji niezawisłości sędziowskiej i niezależności sądów. W uchwale z dn. 6 grudnia 1995 r. Sąd Konstytucyjny Republiki Litewskiej stwierdził, że warunki niezawisłości sędziowskiej można względnie podzielić na trzy grupy: nieusuwalność z urzędu, immunitet sędziowski, gwarancje sędziowskie o charakterze socjalnym 
(materialnym). Te gwarancje niezawisłości inter alia dotyczą wymogów stosowanych wobec kandydatów na sędziego - zgodnie z założeniami Konstytucji i Ustawy Republiki Litewskiej o Sądach, na sędziów mogą być wyznaczone tylko osoby spełniające wysokie wymogi zawodowe i etyczne. Zachowania niezawisłości wymaga również przysięga składana przez sędziów przed rozpoczęciem pełnienia obowiązków.

Właśnie regulacja prawna na poziomie konstytucyjnym zatwierdza podstawowe wymogi dotyczące wyznaczania sędziów, ich kariery zawodowej oraz zwalniania z funkcji.

Założenia art. 112-116 Konstytucji Republiki Litewskiej, regulujące wyznaczanie sędziów (z wyjątkiem sędziów Sądu Konstytucyjnego), karierę zawodową, zwalnianie z obowiązków stosowane wobec poszczególnych grup (osób) sędziów, względnie mogłyby być zaliczane do założeń stosowanych: (1) wobec wszystkich, tj. sędziów wszystkich pionów o kompetencjach ogólnych i sędziów sądów specjalistycznych (administracyjnych) (np. założenia cz. 1, 4, 5, art. 112, 113-115 Konstytucji); (2) sędziów o kompetencjach ogólnych poszczególnych sądów (poszczególnych pionów) i (lub) sędziów sądów specjalistycznych (administracyjnych). Takie są przepisy określające tryb wyznaczania sędziów lub przewodniczącego Naczelnego Sądu Litwy (cz. 1, art. 112), Sądu Apelacyjnego Litwy (cz. 2, art. 112), zwolnienie tych sędziów i przewodniczących z obowiązków w drodze impeachmentu (art. 116). Także przepisy osobno określające tryb wyznaczania oraz zmiany miejsca pracy sędziów oraz przewodniczących wszystkich sądów rejonowych, okręgowych i specjalizowanych, tj. wyznaczania oraz zmiany miejsca pracy sędziów sądów administracyjnych oraz przewodniczących tych sędziów (cz. 2, art. 112).

Sąd Konstytucyjny, komentując te ogólne zasady Konstytucji zatwierdzające prawny status sędziów, zaznaczył, że „wynikające z Konstytucji imperatywy regulacji prawnej formowania korpusu sędziów (wyznaczania, awansu zawodowego, przeniesienia/zmiany miejsca pracy, zwolnienia z obowiązków) są również stosowane mutatis mutandis w regulacji prawnej dotyczącej formowania korpusu sędziów sądów administracyjnych" ${ }^{16}$. Oznacza to między innymi, że podczas wyznaczania sędziów oraz przewodniczących sądów administracyjnych stosowany jest tryb wyznaczania i zwalniania oparty na głównej zasadzie formowania korpusu sędziów wszystkich sądów Republiki Litewskiej; w wyznaczaniu i zwalnianiu sędziów i przewodniczących sądów administracyjnych obu pionów udział bierze instytucja innej władzy państwowej formowana w oparciu o zasadę polityczną (w danym przypadku - władzy wykonawczej). Zgodnie z Konstytucją sędziów sądów administracyjnych oraz przewodniczących tych sędziów wy-

${ }^{16}$ Orzeczenie Sądu Konstytucyjnego Republiki Litewskiej z dn. 9 maja 2006 r. 
znacza i zwalnia Prezydent Republiki Litewskiej ${ }^{17}$. Odpowiednio sędzia sądu administracyjnego nabywa wszelkie uprawnienia do wykonywania władzy sądowniczej po złożeniu przysięgi przed Prezydentem Republiki Litewskiej. Z jednej strony instytucja władzy ustawodawczej, tj. Sejm Republiki Litewskiej, nie bierze udziału w wyznaczaniu sędziów sądów administracyjnych, w odróżnieniu od regulaminu wyznaczania sędziów Naczelnego Sądu Litwy oraz sędziów Sądu Apelacyjnego Litwy. Z drugiej zaś strony w formowaniu korpusu sędziów sądów administracyjnych (podobnie jak w formowaniu składu sędziów sądów powszechnych, jednak inaczej niż w doborze sędziów Sądu Konstytucyjnego) udział bierze specjalna instytucja sędziowska wskazana w cz. 5 art. 112 Konstytucji (tj. Komisja rekrutacyjna dobierająca kandydatów na sędziów ${ }^{18}$. Jak już wielokrotnie podkreślał Sąd Konstytucyjny, wspomniana instytucja kolegialna posiada pewne uprawnienia konstytucyjne oraz uwzględniając zatwierdzoną w Konstytucji pełnowartościowość, samodzielność, niezawisłość władzy sądowniczej oraz konstytucyjną zasadę podziału władzy, stanowi pewną przeciwwagę wobec Prezydenta Republiki Litewskiej w formowaniu korpusu sędziów, a jednocześnie zapewnia partnerstwo i współpracę $\ell^{19}$.

Warto zaznaczyć, że omówiony wynikający z założeń Konstytucji tryb wyznaczania sędziów sądów administracyjnych oraz przewodniczących tych sądów jest zgodny z trybem formowania korpusu sędziów sądów administracyjnych w większości krajów Unii Europejskiej. Przywódca państwa wyznacza sędziów sądów administracyjncyh (oraz ich przewodniczących) np. w Republice Federacyjnej Niemiec, Republice Austrii, Republice Czeskiej, Republice Finlandii, Rzeczypospolitej Polskiej (sędziów sądu administracyjnego wyznacza prezydent), Królestwie Belgii i Królestwie Niderlandów (sędziów sądu administracyjnego wyznacza monarcha), Wielkim Księstwie Luksemburga (sędziów sądu administracyjnego wyznacza Wielki Książę) i in. W wyborze tych sędziów, tj. w formowaniu korpusu sędziów sądów administracyjnych, prawie we wszystkich przypadkach, podobnie jak na Litwie, udział bierze sądowa instytucja samorządowa (tj. specjalna instytucja sędziowska). W poszczególnych przypadkach (np. w Niemczech, Austrii, Czechach) przewidziany jest udział rządu danego państwa (lub poszczegól-

${ }^{17}$ W wyznaczaniu sędziów i przewodniczących Naczelnego Sądu Litwy i Sądu Apelacyjnego Litwy bierze udział Prezydent Republiki Litewskiej i Sejm, tj. instytucje władzy wykonawczej i ustawodawczej (zob. cz. 2-3, Art. 112 Konstytucji Republiki Litewskiej, s. 2-3d).

${ }^{18}$ Orzeczenie Sądu Konstytucyjnego Republiki Litewskiej z dn. 9 maja 2006 r.; Orzeczenie Sądu Konstytucyjnego Republiki Litewskiej z dn. 2 czerwca 2005 r.; Orzeczenie Sądu Konstytucyjnego Republiki Litewskiej z dn. 13 grudnia 2004 r; Orzeczenie Sądu Konstytucyjnego Republiki Litewskiej z dn. 21 grudnia 1999 r.

${ }^{19}$ Orzeczenie Sądu Konstytucyjnego Republiki Litewskiej z dn. 9 maja 2006 r. 
nych ministrów), (np. podczas zatwierdzania lub zgłaszania prezydentowi kandydata do sądu administracyjnego).

Porównując Konstytucję Republiki Litewskiej do konstytucji innych państw Unii Europejskiej zauważymy, że np. zarówno w konstytucji Niemiec, Austrii i Szwecji oraz w konstytucji Czech i Bułgarii struktura sądownictwa administracyjnego jest zatwierdzona explicite, określony jest jej status prawny, określone należne jej miejsce w wymienionej strukturze sądownictwa specjalistycznego. Jednocześnie należy zaznaczyć, że status sędziów Sądu Konstytucyjnego, podobnie jak na Litwie, zasadniczo nie różni się od statusu sędziów innych sądów.

W litewskim systemie prawnym do określenia statusu prawnego sędziów sądów administracyjnych za szczególnie aktualną uważa się zasadę konstytucyjną dotyczącą rozwoju zasady niezawisłości sędziowskiej i niezależności sądów. Jeszcze w 1999 roku $^{20}$ Sąd Konstytucyjny zaznaczył, że „zarówno status prawny sędziego, jak i sądu jest zaliczany do gwarancji niezawisłości sędziowskiej i niezależności sądów, z czego między innymi wynika, że po pierwsze sędzia ze względu na wykonywane obowiązki nie może być zaliczany do urzędników państwowych; po drugie, nie można od niego żądać realizacji jakichkolwiek założeń politycznych".

Odpowiednio, opierając się na konstytucji, należy wysnuć wniosek, że po pierwsze status sędziego sądu administracyjnego Republiki Litewskiej jest wyraźnie oddzielony od statusu urzędnika państwowego (w odróżnieniu od np. Republiki Francuskiej) oraz po drugie - jest zrównany ze statusem prawnym sędziego sądu powszechnego. A to między innymi oznacza istotne, wynikające z Konstytucji, wysokie wymagania zawodowe i etyczne wobec osób kandydujących na stanowisko sędziego sądu administracyjnego oraz podstawowe gwarancje niezawisłości sędziowskiej i niezależności sądów, obejmujące nieusuwalność z urzędu, immunitet sędziowski, gwarancje sędziowskie o charakterze socjalnym (materialnym)"21. Ten wyjątkowy status prawny sędziego wynika z powierzonych mu funkcji sprawowania wymiaru sprawiedliwości. Jak podkreśla Sąd Konstytucyjny, status ten między innymi wynika „Zz założeń Konstytucji, utrwalających nie tylko niezawisłość sędziowską i niezależność sądów podczas sprawowania wymiaru sprawiedliwości, lecz również zakaz zatrudnienia na jakichkolwiek stanowiskach, zakaz dodatkowego zatrudnienia w instytucjach biznesowych, w placówkach handlowych lub jakichkolwiek przedsiębiorstwach czy spółkach prywatnych, zakaz dodatkowego zarobkowania poza wynagrodzeniem sędziowskim oraz wynagrodzeniem za działalność pedagogiczną lub twórczą; zakaz brania

\footnotetext{
${ }^{20}$ Orzeczenie Sądu Konstytucyjnego Republiki Litewskiej z dn. 21 grudnia 1995 r.

${ }^{21}$ Orzeczenie Sądu Konstytucyjnego Republiki Litewskiej z dn. 6 grudnia 1995 r.
} 
udziału w działalności partii politycznych lub organizacji politycznych (art. 113 Konstytucji), zakaz interweniowania w działaność sędziowską, zakaz naruszania immuniteu sędziowskiego i inne"22. Warto zaznaczyć, że zgodnie z Konstytucją i rozwijającą ją doktryną oficjalną Sądu Konstytucyjnego, status sędziów wszystkich pionów i struktur sądownictwa jest jednakowy, zaś różnica $\mathrm{w}$ ich pełnomocnictwach wynika tylko z kompetencji konkretnego sądu, w którym są oni zatrudnieni. Odpowiednio zgodnie z oficjalną doktryną konstytucyjną, różnice w gwarancjach socjalnych (materialnych) sędziów sądów administracyjnych mogą być oparte na wyraźnych, zawczasu znanych kryteriach, nie dotyczących funkcji sprawowania sprawiedliwości podczas rozpatrywania spraw.

Należy również zaznaczyć, że Konstytucja nie zawiera explicite określenia struktury sądownictwa administracyjnego, jednak ani status prawny Naczelnego Sądu Administracyjnego Litwy (jako sądu administracyjnego najwyższej instancji), ani status prawny przewodniczącego sądu administracyjnego pierwszej instancji nie zostały zatwierdzone inter alia, jak również nie zostały zatwierdzone osobliwości statusu przewodniczących sądów poszczególnych pionów. Biorąc pod uwagę doktrynę Sądu Konstytucyjnego, można wywnioskować, że po pierwsze: status przewodniczących sądów administracyjnych cechuje się tym, że zgodnie z Konstytucją przewodniczący zarówno tych, jak i wszystkich pozostałych sądów nie posiadają żadnych innych uprawnień, z wyjątkiem uprawnień nadanych im jako sędziom odpowiedniego sądu, którzy powinni wymierzać sprawiedliwość - rozpatrywać sprawy, a także wynikających z Konstytucji i przepisów prawa uprawnień do organizowania pracy odpowiedniego sądu. Po drugie: status prawny przewodniczącego Naczelnego Sądu Administracyjnego Litwy, jako przewodniczącego sądu najwyższej instancji, wynika ze struktury sądownictwa zatwierdzonej w Konstytucji, jej hierarchii, z której inter alia wynikają uprawnienia do nadzoru nad działalnością administracyjną okręgowych sądów administracyjnych ${ }^{23}$, między innymi - wszczęcie postępowań dyscyplinarnych wobec sędziów tych sądów (ich przewodniczących).

Odpowiednio uważa się obecne przepisy Konstytucji oraz zasady rozwijającej je oficjalnej doktryny konstytucyjnej za wystarczające w konstytucyjnym określeniu statusu sędziego sądu administracyjnego. Z jednej strony, za podstawowe uważane są założenia wyraźnie odróżniające status prawny sędziego sądu administracyjnego od statusu prawnego urzędnika państwowego oraz porównujące go do statusu sędziego sądu powszechnego. Z dru-

\footnotetext{
${ }^{22}$ Orzeczenie Sądu Konstytucyjnego Republiki Litewskiej z dn. 22 padziernika 2007 r.

${ }^{23}$ Pkt 2, cz. 1 art. 104 Ustawy Republiki Litewskiej o sądach.
} 
giej strony, zasady Konstytucji zatwierdzające explicite tryb wyznaczania tych sędziów są istotne dla podkreślenia specyfiki statusu konstytucyjnego sędziego sądu administracyjnego.

\section{Istnienie obiektywnej konieczności wprowadzenia zmian w Konstytucji}

Zapewne nie można powziąć jednoznacznego wniosku o istnieniu obiektywnej konieczności wprowadzenia zmian w Konstytucji, przede wszystkim z powodu braku wyraźnego określenia pojęcia „obiektywna możliwość prawna”, jak również jego charakteru wartościującego. Cz. 1 artykułu 147 Konstytucji określa wyjątkowe prawo podmiotów (nie mniej niż 1/4 posłów na Sejm lub nie mniej niż 300 tys. wyborców) do wniesienia do Sejmu wniosku o wprowadzenie zmian lub uzupełnienia Konstytucji, co oznacza, że przede wszystkim te podmioty, składając wniosek do Sejmu o zmianie lub poprawkach do Konstytucji, mają prawo do oceny obiektywnej konieczności prawnej wniesienia takich zmian ${ }^{24}$. Ostateczną decyzję o istnieniu takiej konieczności podejmuje Sejm (z wyjątkiem przypadków wymienionych w artykule 148 Konstytucji, gdy poszczególne poprawki do Konstytucji można wnieść dopiero, gdy zostaną one poparte przez obywateli w referendum). Ani Konstytucja, ani oficjalna doktryna Sądu Konstytucyjnego nie określają, jakie argumenty lub okoliczności mogłyby uzasadnić (udowodnić) istnienie obiektywnej konieczności prawnej.

Jednak, mówiąc o sądach administracyjnych i potrzebie utrwalenia ich struktury bezpośrednio w Konstytucji, wymienioną powyżej konieczność można uzasadnić przede wszystkim specyfiką sądów administracyjnych (w porównaniu z innymi sądami specjalistycznymi możliwymi do założenia). Uważa się, że potrzebę konstytucyjnego uregulowania mogłaby uzasadnić waga kwestii przydzielonych do kompetencji tych sądów (nie tylko dla stron-uczestników sporu, lecz i dla całego społeczeństwa), ich rola w utrwalaniu zaufania społeczeństwa do instytucji państwowych oraz należyte zapewnienie realizacji zasad konstytucyjnych, że instytucje władzy służą ludziom, a także przekonanie o znaczeniu decyzji sądów administracyjnych w zapewnieniu należytej realizacji funkcji państwa prawa.

Z drugiej strony należy również wspomnieć, że system sądów administracyjnych jest tylko jednym z trzech funkcjonujących na Litwie, nie został określony w Konstytucji, chociaż jak wspominaliśmy powyżej, jest nie mniej

${ }^{24}$ Orzeczenie Sądu Konstytucyjnego Republiki Litewskiej z dn. 24 stycznia 2014 r. 
ważny. W tym kontekście można wspomnieć prof. M. Römera, który podkreślał, że status sądu administracyjnego (prawa administracyjnego) powinien opierać się na niezależności od innych władz, tj. na „zasadach wydelegowanej niezależności”, ponieważ tylko taka zasada może powodować, że ta instytucja będzie wymierzała sprawiedliwość i broniła jej w rządzeniu państwem. Profesor był przekonany, że bez zapewnienia formalnych gwarancji szacunku do sądu nie można zapewnić w pełni wartościowej władzy sądowniczej i jej niezależności ${ }^{25}$.

W dążeniu do tych celów uważa się, że zatwierdzenie prawne na poziomie ustawowym nie stanowi wystarczającej gwarancji, zwłaszcza że procedura ustawodawcza (zmian w ustawodawstwie) jest dość prosta.

${ }^{25} \mathrm{~J}$. Žilys, Administraciniu teisès aktu teisètumo problema prof. Mykolo Romerio mokslo darbuose, „Jurisprudencija” 2005, t. 64 (56), s. 22. 